\title{
$O$ trabalho e o afeto: prazer e sofrimento no trabalho dos professores da escola pública de Brasília
}

Carolina Grande

Curso: Mestrado em Sociologia

Data da defesa: 14 de agosto de 2009

Orientadora: Prof ${ }^{a} \operatorname{Dr}^{a}$ Analía Laura Soria Batista 


\section{Resumo}

O tema prazer e sofrimento na profissão docente é abordado de forma geral, e, mais especificamente, no ensino médio da escola pública brasileira. O objetivo principal é comunicar os resultados da observação participante realizada no turno vespertino de uma escola pública do Distrito Federal. Com base nas representações sociais sobre prazer e sofrimento construídas pelo grupo observado, buscou-se identificar quais fatores originam um e/ou outro desses sentimentos, ao mesmo tempo em que se analisa a utilização de mecanismos de enfrentamento da realidade cotidiana da organização do trabalho no contexto observado.

Alicerçada na Psicodinâmica do Trabalho de Dejours, nos estudos de Moscovici sobre representações sociais e na aplicação in loco da metodologia do sociodrama pedagógico, a pesquisa de campo propiciou entender os vínculos entre prazer, sofrimento e a profissão docente, a influência dos fatores constitutivos da real organização do trabalho sobre a saúde dos professores participantes e a importância da subjetividade de cada um perante as oportunidades e dificuldades vivenciadas.

Palavras-chave: trabalho; trabalho docente; prazer e sofrimento; representação social; identidade profissional. 